\title{
Evaluation of Some Soil Test Methods for Available Phosphorus and Critical Level of French bean in Acid Soils of Thoubal District, Manipur (India)
}

\author{
Herojit Singh Athokpam*, Rabichandra Khangembam, Nandini Chongtham, \\ Naorem Brajendra Singh, K. Nandini Devi, N. Gopimohan Singh and P.T. Sharma
}

College of Agriculture, Central Agricultural University, Imphal-795004, India

*Corresponding author

A B S T R A C T

\begin{tabular}{|l|}
\hline Ke y w o r d s \\
$\begin{array}{l}\text { Phosphorus, Acid soils, } \\
\text { French bean, Critical } \\
\text { limit, Bray's per cent } \\
\text { yield }\end{array}$ \\
\hline Article Info \\
\hline $\begin{array}{l}\text { Accepted: } \\
\text { 02 May 2018 } \\
\text { Available Online: } \\
\text { 10 June 2018 }\end{array}$ \\
\hline
\end{tabular}

\section{Introduction}

Phosphorus is the second most important plant nutrient after nitrogen for agricultural production in most regions of the world. Phosphorus is used in the plant for energy storage and transfer, maintenance and transfer of genetic code and is structural component of cells and many biochemicals. Phosphorus deficiencies results in poor root growth, stunted top growth, reduced yield and crop quality along with delayed maturity (Mishra, 2012). In severe cases, phosphorus deficiency can cause yellowing and senescence of leaves. In many acidic soils in developing countries, phosphorus deficiency is the main limiting factor for crop production and therefore, requires the phosphorus fertilization for optimum plant growth and production of food and fibre (Attar, 2014). Phosphorus also reduces the harmful effect of excess nitrogen and imparts resistant to plant against disease. Supply of phosphorus to leguminous crops increase the numbers and size of root nodules and nitrogen fixing potentiality of Rhizobium, so it is essential for obtaining the higher yield of crop (Patil and Jadav, 1994).

Phosphorus deficiency in plants has been reported from various parts of India. Soil testing allows one to access a soil's current nutrient status and decide on appropriate 
fertilizer rates to maximize crop production. An extraction method must be selected which gives the good indication of the amount of nutrient in the soils that available to the particular crops for the soils in the region in which the test is to be used. This will be done by sampling a large number of soil representatives of the region and growing crops on these soils in green house. This eliminates the effects of climatic variation from location to location (Watham et al., 2014). The amount of nutrient absorbed by the plants is then correlated to the amount of the available nutrient across the range of soils. Fertilizer recommendations for phosphorus generally are based on soil testing. The increasing demand for soil testing necessitates the use of more efficient method for soil testing. One possibility for improving the laboratory efficiency would be to use a single extractant for multiple purposes (Antonio and Mallarino, 1995). The most appropriate soil test method for soil would be one which extracts predominantly that fraction of phosphorus playing the major role towards plant uptake. Therefore, the present investigation was planned to select the most suitable extractant which predict the availability of phosphorus to French bean (Contender) grown in acid soil of Thoubal district, Manipur.

\section{Materials and Methods}

Twenty soil samples $(0-15 \mathrm{~cm})$ were collected from various locations of the paddy fields of Thoubal district, Manipur. The soil texture was analyzed by the hydrometer method (Bouyoucos, 1951). These soil samples were analyzed for $\mathrm{pH}$, EC, total $\mathrm{N}$ and $\mathrm{K}$ using procedures as described by Jackson (1973), available N (Subbiah and Asija, 1956) and CEC as described by Borah et al., (1987). Exchangeable $\mathrm{Ca}$ and $\mathrm{Mg}$ were analyzed as outlined by Chopra and Kanwar (1976). Soil organic carbon was determined by wet oxidation method of Walkley and Black (1934). To test the suitability, six soil test methods were used i.e. Bray- $\mathrm{P}_{1}$ (Bray and Kurtz, 1945), Bray-P $\mathrm{P}_{2}$ (Bray and Kurtz, 1945), Olsen P (Olsen et al., 1954), Truog P (Truog, 1930), Mehlich-P $P_{1}$ (Mehlich, 1978) and Morgan P (Morgan, 1937). The soil samples were shaken for two minutes with soil to solution ratio and extractable phosphorus was determined spectrophotometrically.

Three $\mathrm{kg}$ of soil were filled in pots and phosphorus were applied $0,60,80 \mathrm{~kg} \mathrm{P}_{2} \mathrm{O}_{5}$ $\mathrm{ha}^{-1}$ through single super phosphate. The treatments were replicated thrice in completely randomized design. A basal dose of $\mathrm{N}$ and $\mathrm{K}_{2} \mathrm{O} @ 50$ : $60 \mathrm{~N}: \mathrm{K}_{2} \mathrm{O}$ ha $^{-1}$ in the form of urea and muriate of potash in each pot. French bean cv. Contender were sown and thinned to three plants in each pot after 7 days. The moisture level was maintained at field capacity level in all the pots by irrigating with distilled water as and when required.

The crop was harvested 40 days of growing. The plant samples were washed to remove dirt and then oven dried at $65^{\circ} \mathrm{C}$ for 48 hours and the dry matter yield was recorded. The samples were ground and powdered samples were analyzed for nitrogen by macrokjeldahl method, phosphorus by tri-acid digestion using vanadomolybdophosphoric acid yellow colour method by spectrophotometry and plant potassium by flame photometry method (Jackson, 1973). The critical limits of soil and plant were determined by technique of Cate and Nelson (1965). Bray's per cent yield and uptake of French bean was calculated as:

Yield without fertilizer

Bray's per cent yield = ------------------- x 100

Maximum yield in fertilizer treated pots

Uptake without fertilizer

Bray's per cent uptake = ----------------- x 100

Maximum uptake in fertilizer treated pots 


\section{Results and Discussion}

Results shows that soil $\mathrm{pH}$ values varied from 4.61 to 6.26 (mean 5.48), EC ranged from 0.12 to $0.33 \mathrm{dSm}^{-1}$ at $25^{\circ} \mathrm{C}$ (mean $0.19 \mathrm{dSm}^{-1}$ ), CEC values varied from 9.21 to 35.71 [cmol $^{2}$ $\left(\mathrm{p}^{+}\right) \mathrm{kg}^{-1}$ ] with mean value of 19.33 [ $\mathrm{cmol}\left(\mathrm{p}^{+}\right)$ $\mathrm{kg}^{-1}$ ], organic carbon content ranged from 0.99 to 2.41 per cent (mean 1.65 per cent) and total $\mathrm{N}$ varied from 0.10 to 0.40 per cent (mean 0.25 per cent). The available $\mathrm{N}$ and $\mathrm{K}$ content varied from 246.21 to $408.38 \mathrm{~kg} \mathrm{ha}^{-1}$ (Mean 325.76 ) and 162.61 to $264.99 \mathrm{~kg} \mathrm{ha}^{-1}$ (mean 210.75), respectively. The studied soils were clay in textural class (Table 1).

\section{Extraction of available phosphorus}

The mean extractable phosphorus by various method (Table 2) followed in descending order: Bray- $\mathrm{P}_{2}>$ Bray- $\mathrm{P}_{1}>$ Olsen-P > Mehlich- $\mathrm{P}_{1}>$ Truog-P $>$ Morgan-P. The different behavior of the different extractants could be due to their selectivity in solubilizing specific fractions of phosphorus.

The higher solubility in Bray $\mathrm{P}_{2}$ may be due to its relatively higher strength of acidity and complexing of $\mathrm{Al}^{3+}$ and $\mathrm{Fe}^{3+}$ ions with $\mathrm{F}^{-}$ions and consequent release of $\mathrm{P}$ adsorbed by these trivalent ions, (Ballard,1974).The lowest quantity of $\mathrm{P}$ was extracted by Morgan reagent.

This may be due to the presence of weekly buffered salt solution such as acetic acidsodium acetate solution (Hesse, 1994). Bray$\mathrm{P}_{1}$, Olsen, Troug and Mehlich methods extracted lesser amount of $\mathrm{P}$ might be due to mild alkaline nature which displaces $\mathrm{P}$ from the surface of $\mathrm{Ca}, \mathrm{Al}$ and $\mathrm{Fe}$ phosphate by decreasing $\mathrm{Ca}$ activity and repression of $\mathrm{Al}^{3+}$ and $\mathrm{Fe}^{3+}$ activities respectively (Jackson, 1973). The finding is in conformity with finding of Watham et al., (2014), Meitei et al., (2015) and Athokpam et al., (2016).

\section{Correlation between the extractants}

The coefficient of correlation values between the different methods of phosphorus extractants (Table 3) revealed that the extractants were closely interrelated.

Such a close relationship between the various extractants suggested that these extractants were able to extract more or less the same forms of phosphorus indicating the existence of dynamic equilibrium among different forms of phosphorus but relatively to different degrees.

This observation was corroborated by Meitei et al., (2015). Similarly, Battacharya and Singh (1990) and Jaggi (1991) reported that the transformation and availability of $\mathrm{P}$ in the soils was dependent on its various forms.

\section{Correlation of soil phosphorus with plant yield and uptake}

The simple correlation coefficients between the various extractants and yield parameters are presented in Table 4 . The data revealed that all the extractants showed positive and significant correlation with Bray's per cent yield of French bean cv. Contender with varying degree. Out of six extractants, only three were significantly and positively correlated with Bray's per cent uptake. Among the extractant used Bray- $\mathrm{P}_{1}$ is most suitable extractant for determining available phosphorus as the degree of co-efficient of correlation between the quantities of phosphorus extracted by this extractant and yield and uptake by the French bean were of higher order and showed higher degree of coefficient of correlation with Bray's per cent yield and uptake with ' $r$ ' values of $0.679 * *$ and $0.629^{* *}$, respectively. The extractant suitability was in the order: Bray- $\mathrm{P}_{1}>$ Morgan-P $>$ Mehlich- $\mathrm{P}_{1}>$ Bray- $\mathrm{P}_{2}>$ Olsen-P $>$ Truog-P. 
Table.1 Some physio - chemical properties of the soils

\begin{tabular}{|c|c|c|c|c|c|c|c|c|c|c|c|c|}
\hline & $\mathrm{pH}$ & EC & $\mathrm{OC}$ & $\begin{array}{c}\text { Total } \\
\mathbf{N}\end{array}$ & $\mathbf{A v} \mathbf{N}$ & Av $\mathbf{K}$ & $\mathrm{Ca}$ & Mg & CEC & & Texture & \\
\hline $\begin{array}{c}\text { Soil } \\
\text { sample }\end{array}$ & & $(\mathrm{dSm}-1)$ & $(\%)$ & $\%$ & $\left(\mathrm{kgha}^{-1}\right)$ & $\left(\mathrm{kgha}^{-1)}\right.$ & $\begin{array}{c}{[\mathrm{cmol}(\mathrm{p}+)} \\
\mathrm{kg}^{-1]}\end{array}$ & $\underset{\mathrm{kg}^{-1]}}{[\mathrm{cmol}(\mathrm{p}+)}$ & $\begin{array}{l}{[\mathrm{cmol}(\mathrm{p}+)} \\
\mathrm{kg}^{-1]}\end{array}$ & Sand $\%$ & Silt\% & Clay\% \\
\hline 1 & 5.21 & 0.13 & 1.43 & 0.19 & 246.21 & 215.88 & 2.13 & 1.99 & 11.10 & 45.93 & 19.27 & 34.80 \\
\hline 2 & 4.77 & 0.17 & 1.11 & 0.35 & 305.18 & 221.63 & 2.63 & 2.49 & 12.48 & 31.67 & 24.96 & 43.37 \\
\hline 3 & 5.17 & 0.24 & 1.71 & 0.20 & 389.08 & 193.24 & 2.35 & 2.22 & 14.94 & 39.87 & 25.30 & 34.83 \\
\hline 4 & 5.94 & 0.18 & 1.96 & 0.27 & 342.60 & 227.63 & 2.62 & 2.24 & 31.34 & 26.22 & 29.37 & 44.42 \\
\hline 5 & 5.47 & 0.20 & 2.02 & 0.38 & 352.98 & 206.34 & 3.56 & 3.47 & 30.25 & 16.06 & 24.08 & 59.86 \\
\hline 6 & 5.01 & 0.15 & 1.51 & 0.16 & 333.16 & 184.59 & 2.35 & 2.24 & 16.32 & 43.85 & 28.56 & 27.59 \\
\hline 7 & 4.61 & 0.12 & 1.00 & 0.10 & 250.85 & 238.65 & 1.54 & 1.45 & 9.21 & 63.11 & 12.12 & 24.78 \\
\hline 8 & 5.47 & 0.13 & 0.99 & 0.28 & 272.98 & 203.68 & 1.88 & 1.87 & 18.76 & 21.72 & 23.26 & 55.02 \\
\hline 9 & 5.60 & 0.17 & 1.85 & 0.27 & 285.41 & 197.49 & 3.46 & 3.44 & 26.28 & 19.43 & 20.18 & 60.38 \\
\hline 10 & 5.95 & 0.24 & 1.24 & 0.36 & 305.59 & 214.50 & 1.82 & 1.74 & 18.44 & 10.54 & 18.97 & 70.49 \\
\hline 11 & 5.41 & 0.22 & 2.02 & 0.12 & 267.20 & 227.21 & 4.30 & 4.23 & 20.35 & 33.93 & 12.71 & 53.35 \\
\hline 12 & 5.51 & 0.21 & 1.95 & 0.29 & 382.23 & 221.21 & 4.96 & 4.76 & 23.39 & 16.65 & 29.18 & 54.17 \\
\hline 13 & 5.29 & 0.14 & 1.34 & 0.20 & 372.14 & 200.26 & 2.04 & 1.90 & 17.48 & 7.31 & 19.31 & 73.38 \\
\hline 14 & 5.84 & 0.16 & 1.72 & 0.35 & 366.39 & 209.05 & 4.71 & 4.54 & 22.51 & 24.67 & 34.79 & 41.14 \\
\hline 15 & 6.26 & 0.33 & 2.41 & 0.40 & 408.38 & 264.99 & 5.45 & 5.35 & 35.71 & 4.45 & 22.49 & 73.07 \\
\hline 16 & 5.79 & 0.25 & 2.21 & 0.25 & 365.56 & 163.85 & 5.07 & 4.97 & 14.45 & 7.02 & 21.07 & 71.90 \\
\hline 17 & 6.09 & 0.14 & 1.17 & 0.25 & 308.82 & 236.45 & 2.24 & 2.14 & 13.26 & 24.15 & 14.85 & 61.00 \\
\hline 18 & 5.11 & 0.16 & 2.14 & 0.27 & 353.58 & 248.97 & 4.14 & 4.08 & 26.61 & 7.29 & 48.14 & 44.57 \\
\hline 19 & 5.33 & 0.15 & 2.17 & 0.31 & 309.15 & 176.15 & 2.47 & 2.49 & 13.82 & 34.56 & 30.61 & 34.84 \\
\hline 20 & 5.82 & 0.29 & 0.99 & 0.15 & 297.80 & 162.61 & 5.06 & 4.94 & 9.87 & 11.93 & 27.65 & 60.42 \\
\hline Mean & 5.48 & 0.19 & 1.65 & 0.25 & 325.76 & 210.75 & 3.24 & 3.14 & 19.33 & 24.49 & 24.34 & 51.17 \\
\hline
\end{tabular}


Table.2 Amount of phosphorus $\left(\mathrm{kg} \mathrm{P}_{2} \mathrm{O}_{5} \mathrm{ha}^{-1}\right)$ of the soils extracted by various extractants

\begin{tabular}{|c|c|c|c|c|l|c|}
\hline Soil sample & BrayP $_{\mathbf{1}}$ & Bray $_{\mathbf{2}}$ & Olsen- & Mehlich- & Truog- & Morgan- P \\
\hline $\mathbf{1}$ & 7.61 & 16.28 & 16.59 & 15.60 & 9.01 & 8.79 \\
\hline $\mathbf{2}$ & 19.55 & 18.83 & 15.96 & 16.31 & 11.31 & 8.20 \\
\hline $\mathbf{3}$ & 22.60 & 19.65 & 13.26 & 18.12 & 7.47 & 9.11 \\
\hline $\mathbf{4}$ & 20.40 & 15.47 & 14.16 & 17.53 & 11.25 & 8.81 \\
\hline $\mathbf{5}$ & 16.14 & 14.94 & 14.14 & 20.77 & 7.47 & 10.44 \\
\hline $\mathbf{6}$ & 19.83 & 15.38 & 18.81 & 18.67 & 14.52 & 9.38 \\
\hline $\mathbf{7}$ & 4.53 & 4.84 & 5.58 & 2.22 & 4.19 & 1.12 \\
\hline $\mathbf{8}$ & 16.59 & 14.46 & 15.70 & 14.15 & 8.65 & 7.11 \\
\hline $\mathbf{9}$ & 20.38 & 21.57 & 26.71 & 20.08 & 16.87 & 9.87 \\
\hline $\mathbf{1 0}$ & 21.64 & 19.45 & 14.50 & 13.57 & 9.23 & 9.07 \\
\hline $\mathbf{1 1}$ & 20.89 & 20.76 & 16.59 & 19.14 & 10.79 & 9.62 \\
\hline $\mathbf{1 2}$ & 15.94 & 20.87 & 11.78 & 14.83 & 0.85 & 6.84 \\
\hline $\mathbf{1 3}$ & 16.64 & 21.68 & 14.33 & 16.01 & 11.31 & 9.44 \\
\hline $\mathbf{1 4}$ & 21.37 & 18.44 & 25.78 & 17.00 & 8.73 & 8.54 \\
\hline $\mathbf{1 5}$ & 31.12 & 24.13 & 31.49 & 23.60 & 23.75 & 11.84 \\
\hline $\mathbf{1 6}$ & 27.49 & 17.76 & 27.20 & 20.83 & 20.77 & 10.47 \\
\hline $\mathbf{1 7}$ & 12.95 & 14.64 & 9.36 & 16.28 & 10.83 & 8.18 \\
\hline $\mathbf{1 8}$ & 19.70 & 15.95 & 26.94 & 18.39 & 9.41 & 9.21 \\
\hline $\mathbf{1 9}$ & 20.85 & 17.60 & 13.20 & 15.72 & 10.57 & 8.59 \\
\hline $\mathbf{2 0}$ & 17.77 & 13.34 & 19.38 & 16.02 & 11.03 & 8.05 \\
\hline Mean & 18.69 & 17.30 & 17.57 & 16.74 & 11.40 & 8.63 \\
\hline
\end{tabular}

Table.3 Correlation of co-efficient among the various extractants

\begin{tabular}{|c|r|r|r|r|r|l|}
\hline Extractant & Bray $\mathbf{P}_{\mathbf{1}}$ & \multicolumn{1}{|c|}{ Bray $\mathbf{P}_{\mathbf{2}}$} & \multicolumn{1}{|c|}{ Olsen-P } & Mehlich-P & Truog-P & Morgan-P \\
\hline Bray P-1 & 1 & $0.686 * *$ & $0.693 *$ & $0.747 * *$ & $0.714 * *$ & $0.738 * *$ \\
\hline Bray P-2 & & 1 & $0.489 *$ & $0.703 * *$ & $0.558 * *$ & $0.752 * *$ \\
\hline Olsen-P & & & 1 & $0.684 * *$ & $0.718 * *$ & $0.639 * *$ \\
\hline Mehlich-I & & & & 1 & $0.667 * *$ & $0.954 * *$ \\
\hline Truog-P & & & & & 1 & $0.626 * *$ \\
\hline Morgan-P & & & & & & 1 \\
\hline
\end{tabular}

Table.4 Simple correlation coefficient between different extractants and yield parameters of French bean

\begin{tabular}{|l|c|c|c|c|l|}
\hline Extractant & $\begin{array}{c}\text { Dry Matter yield } \\
\text { (control) }\end{array}$ & $\begin{array}{c}\text { P content } \\
\text { (control) }\end{array}$ & $\begin{array}{c}\text { Total P uptake } \\
\text { (control) }\end{array}$ & $\begin{array}{c}\text { Bray's\% } \\
\text { yield }\end{array}$ & $\begin{array}{l}\text { Bray's \% } \\
\text { uptake }\end{array}$ \\
\hline Bray P1 & $0.702^{*}$ & $0.578^{*}$ & $0.688^{* *}$ & $0.679 * *$ & $0.629 * *$ \\
\hline Bray P2 & $0.524^{*}$ & $0.486^{*}$ & $0.553^{*}$ & $0.461 *$ & 0.416 \\
\hline Olsen-P & $0.450^{*}$ & 0.431 & $0.510^{*}$ & $0.443^{*}$ & 0.405 \\
\hline Mehlich-P & $0.479 *$ & $0.499^{*}$ & $0.512^{*}$ & $0.526^{*}$ & $0.480^{*}$ \\
\hline Truog-P & 0.441 & 0.406 & $0.513^{*}$ & $0.410^{*}$ & 0.362 \\
\hline Morgan-P & 0.428 & 0.445 & $0.452^{*}$ & $0.528^{*}$ & $0.486^{*}$ \\
\hline
\end{tabular}


Fig.1 Relationship between the soil phosphorus and relatively yield of French bean

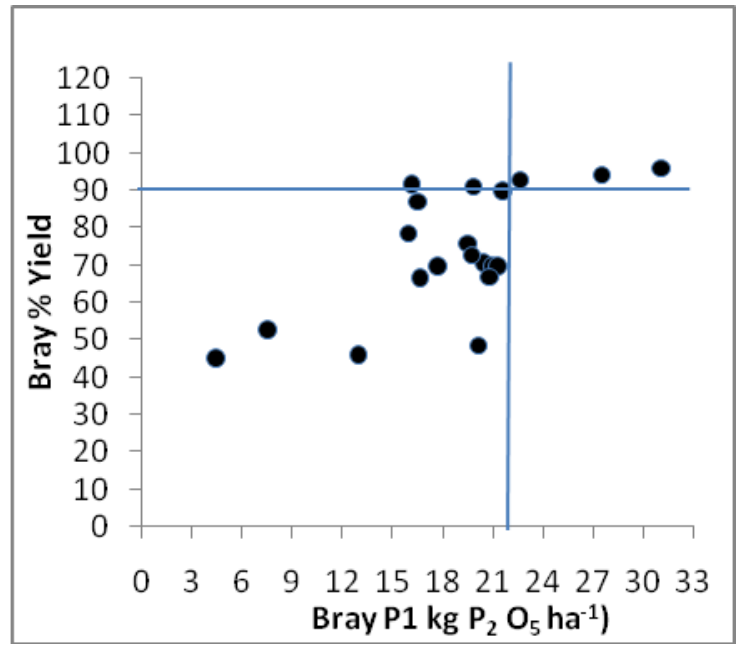

Fig.2 Relationship between the plant P concentration and relatively yield of French bean

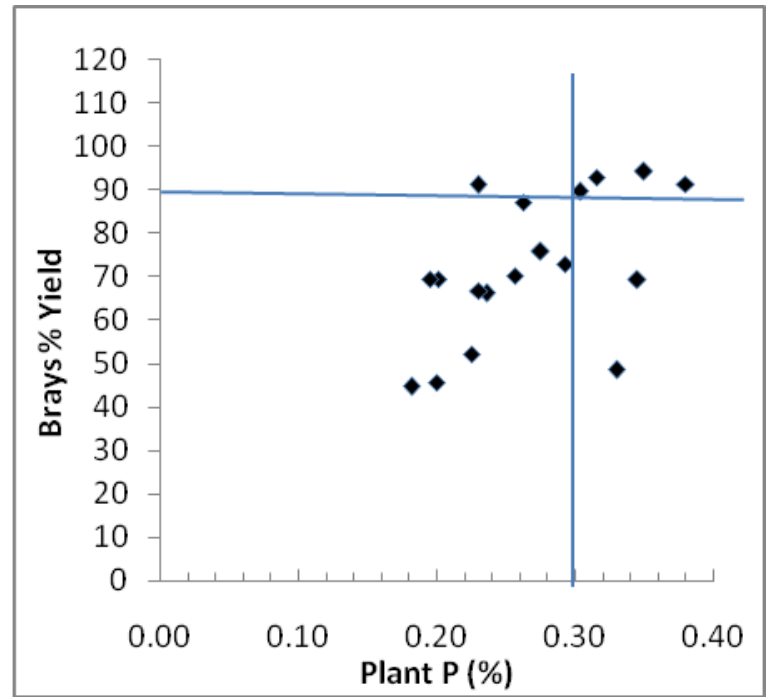

Critical level of phosphorus in soil and plant

It was observed that the critical level of phosphorus in soils for growing of French bean plants varied with method of phosphorus extraction.

According to graphical procedure of Cate and Nelson (1965), the critical level of soil ranged from 10.0 to $23.6 \mathrm{~kg} \mathrm{P}_{2} \mathrm{O}_{5} \mathrm{ha}^{-1}$. A high degree of correlation between Bray- $\mathrm{P}_{1}$ extractant and Bray's per cent yield indicated $21.2 \mathrm{~kg} \mathrm{P}_{2} \mathrm{O}_{5}$ $\mathrm{ha}^{-1}$ (Fig. 1) as the critical limit of available phosphorus in these soils for demarcating the phosphorus responsive soil from the unresponsive soil ones.

The result indicated that the critical level of phosphorus concentration in French bean was found 0.29 per cent according to the graphical procedure of Cate and Nelson (1965) using scatter diagram (Fig. 2), partitioning the two dimensional percentage yield versus phosphorus content in 40 days old French bean plants (control) scattered into two group. 


\section{References}

Antonio, P. and Mallarino, 1995. Proceeding of the twenty-five north central extension industry of soil fertility conference. Potash and Phosphate Institute, Manhattan vol. 11, University of Minnesota.

Athokpam, H., Ghosh, G.K., Athokpam, H.S., Wani, S.H., Akoijam, S. and Ningthoujam, R. 2016. Evaluation of some soil test methods in acid soils for available phosphorus for pea of Senapati district of Manipur (India). International Journal of Agriculture, Environment and Biotechnology. 9(1): 63-68.

Attar, H.A. 2014. Phosphorus availability and proton efflus of nodulated root varies among common bean genotypes (Phaseolus vulgaris) in Rhizobus. International Journal of Agriculture, Environment and Biotechnology. 7(2): 391-402.

Ballard, R. 1974. Extractability of reference phosphates by soil test reagents in absence and presence on soils. Soils and Crop Science Society of Florida Proceedings. 33: 169-174.

Bhattacharya, N.G. and Singh, B. 1990. Transformation of applied phosphorus and its availability in acid soils. Two and a Bud. 37(1): 24-30.

Borah, D.K., Bordoloi, P.K., Karmakar, R.M., Baruah, N.G. and Das, M. 1987. Practical Manual of Fundamental of Soil Science (Part-III), Jorhat, Assam.

Bouyoucos, G.J. 1951. Soil Science. 23: 319343.

Bray, R.H. and Kurtz, L.T. 1945. Determination of total organic and available forms of phosphate in soils. Soil Science. 59:39-45.

Cate, R.B. and Nelson, L.A. 1965. Graphical procedure for critical limits of nutrients.
Proceedings of Soil Science Society of America. 89: 658.

Chopra, S.L. and Kanwar, J. 1976. Analytical Agricultural Chemistry. Kalayani, Publisher. Ludhiana, New Delhi.

Hesse, P.R. 1994. A Textbook of Soil Chemical Analysis. Satish Kumar Jain for CBS Publishers and Distributors, Delhi. pp. 255-300.

Jackson, M.L. 1973. Soil Chemical Analysis. Prentice Hall of India Pvt. Ltd., New Delhi.

Jaggi, R.C. 1991. Inorganic phosphate fractions as related to some representative soils of Himachal Pradesh. Journal of the Indian Society of Soil Science. 39(3): 567-568.

Mehlich, A. 1978. New extractant for soil test evaluation of phosphorus, potassium, magnesium, calcium, sodium, manganese and zinc. Communication in Soil Science and Plant Analysis. 15: 1409-1416.

Meitei, W.H., Athokpam, H.S., Singh, R.K.K., Watham, L., Chongtham, N., Singh, N.B., Singh, K.L. and Singh, N.J. 2015. Evaluation of some soil test methods in acid soils for available phosphorus for soybean of Imphal East district, Manipur (India). African Journal of Agricultural Research. 10(8): 767-771.

Mishra, L.K. 2012. Effect of phosphorus and zinc fertilization on biochemical composition of wheat. The Bioscan. 7(3): 445-449.

Morgan, M.F. 1937. The Universal Soil Testing System, Bulletin 392. Connecticut Agricultural Experimental Station, New Haven.

Patil, B.P. and Jadav, M.S. 1994. Effect of fertilization and Rhizobium on yield of green gram on medium black soil of Konkan. Journal of the Indian Society of Coastal Agricultural Research. 12(1): 17-22. 
Subbiah, B.V. and Asija, G.L. 1956. A rapid procedure for estimation of available $\mathrm{N}$ in soils. Current Science. 25: 259-260.

Truog, E. 1930. Determination of readily available phosphorus of soils. Journal of the American Society of Agronomy. 22: 874-882.

Walkley, A. and Black, I.A. 1934. An examination of the Degtjareff method determining soil organic matter and a proposed modification of the chromic acid titration method. Soil Science. 34: 29-38.

Watham, L., Athokpam, H.S., Meitei, W.H., Chongtham, N., Devi, K.N., Singh, N.B., Singh, N.G. and Singh, N.J. 2014. Evaluation of some soil methods for available phosphorus and its critical limits for black gram in acid soils of Imphal West district, Manipur (India). The Ecoscan. 8(3\&4): 199-202.

\section{How to cite this article:}

Herojit Singh Athokpam, Rabichandra Khangembam, Nandini Chongtham, Naorem Brajendra Singh, K. Nandini Devi, N. Gopimohan Singh and Sharma, P.T. 2018. Evaluation of Some Soil Test Methods for Available Phosphorus and Critical Level of French bean in Acid Soils of Thoubal District, Manipur (India). Int.J.Curr.Microbiol.App.Sci. 7(06): 117-124. doi: https://doi.org/10.20546/ijcmas.2018.706.016 